\title{
Russian industry discourses on climate change
}

Ellie Martus

WIRL-COFUND Fellow, Institute of Advanced Study, University of Warwick

ORCID 0000-0001-5433-9120

\section{Abstract}

How has Russian industry responded to climate change? Understanding industry narratives on climate change is an important element of Russia's broader climate change discourse. This chapter focuses specifically on Russia's largest oil and gas companies, which hold significant responsibility for the country's GHG emissions and whose participation in global attempts to address climate change is vital. It considers how companies have conceptualised the issue of climate change, and how this links to broader narratives within Russia and internationally. The evidence indicates an emphasis on energy saving and efficiency, technology and industrial modernisation, and limited direct engagement on climate change policy and mitigation efforts. Oil and gas industry discourse on climate change is set within a market-based framework and contiguous with government policy.

\section{Introduction}

Industry and business actors are key players in the fight against climate change. They hold significant responsibility when it comes to greenhouse gas (GHG) emissions, and their participation is vital in global efforts to reduce emissions. They can be powerful political and 
economic actors, with the ability to shape government policy and wider discussions in society on climate. It matters, therefore, what these companies say and do in relation to climate change.

This discussion will concentrate specifically on oil and gas companies. Overall, the energy sector is the largest contributor to Russia's GHG emissions. According to the UN Framework Convention on Climate Change (UNFCCC), the energy sector was responsible for $82.16 \%$ of Russia's total GHG emissions (without land use, land use change and forestry) in 2012 (UNFCCC, 2015). The key question this chapter seeks to explore relates to how Russian industry understands the issue of climate change. That is, do companies acknowledge climate change as an issue? If so, how do they talk about climate change? How have they understood and conceptualised the issue? What are their priorities, how do they seek to address climate change, and what policy solutions do they advocate? It is about the disclosure of information, corporate understanding and framing, and industry narratives on climate change. Understanding industry narratives on climate change is an important element of Russia's broader climate change discourse.

There is a substantial body of literature which explores the relationship between climate, politics, and business. The role of business in governing climate change and shaping policy has featured heavily, with works examining the push for self-regulation and other forms of private governance (Hoffman, 2005; Bulkeley and Newell, 2015), support for emissions trading schemes (Meckling, 2011), and the emphasis on management processes, policy influence and image rather than meaningful GHG reductions (Jones and Levy, 2007), for example. 
As early entrants into global climate politics, fossil fuel companies have been the focus for much research, with works charting the aggressive lobbying against action on climate change by companies such as Exxon and Chevron (Newell and Paterson, 1998: 683). After this initial opposition, attention shifted to the emergence of a second stream of corporate political involvement, with Kolk and Pinkse noting the move towards engagement with market responses to climate change (2007: 202). These divergent policy responses from the oil industry have been charted by Pulver (2007). Research has also expanded on different strategies adopted by oil multinationals (Levy \& Kolk, 2002; van den Hove et al., 2002; Levy, 2005).

While Russia has been largely excluded from this literature, a limited number of works have touched on the role of Russian business actors in climate politics, including through their support for ratification of the Kyoto Protocol (Andonova, 2008), and interest in Joint Implementation projects (Korppoo, 2007). The attitudes of specific industrial sectors within Russia towards climate change has been thus far overlooked, with the exception of work by the present author on the metals and mining sector which pointed to the strong resistance to climate policy from the coal industry (Martus, 2018).

This chapter also draws on literature which explores discourse on climate change, particularly from a business or industry perspective. Works have explored a variety of themes, including for example, ExxonMobil's corporate discourse on global warming, with Livesey examining how public advertisements were used by the company to "promote particular corporate understandings of the problem of the natural environment and legitimate the corporate stance' 
(2002: 118). There are a number of competing frames, or discourses, on climate change: including Hajer's (1995) 'environmental modernization'. According to this, climate change action is framed within an economic development paradigm (Taylor, 2013: 26). As Levy notes, this discourse 'puts its faith in the technological, organizational, and financial resources of the private sector, voluntary partnerships between government agencies and business, flexible market-based measures, and the application of environmental management techniques' (2005: 93). Climate change becomes a problem that can be solved through the market. This chapter explores how the Russian experience fits within this broader context.

This chapter proceeds as follows. A brief introduction to the core tenets of Russian government policy and relations with the oil and gas sector is given. Second, methodological considerations arising from this study are discussed. An analysis of climate change discourse within the oil and gas sector is then presented, followed by a discussion of key implications arising from this research, and conclusions.

\section{Oil, gas and the state in Russia}

The oil and gas sector plays a central role in Russia's economy. In 2016 for example, oil and gas revenues brought in 4844 billion roubles to the federal budget, or $36 \%$ of total revenue for the year (Ministerstvo Finansov, 2018). There are a number of large companies operating in the sector, several of which are examined below. These companies are both private and stateowned, with the oil and gas sector having undergone considerable changes since the end of the Soviet Union. The sale of previously state-owned enterprises in the 1990s (including the notorious 'loan-for-shares' auctions) saw the oil sector largely privatised by the end of 1998 and fragmented (Gustafson, 2012: 98-9). The industry then began a process of reconsolidation, with private oligarch-owned companies like Lukoil, Surgutneftegaz and Yukos emerging 
(Gustafson, 2012: 100-1). Since 2002 however, there has been an increasing state presence in the industry, with Rosneft emerging as a particularly powerful actor. The gas sector in Russia is even more concentrated, and dominated by state-owned company Gazprom. ${ }^{1}$

While Russia's overall approach to climate policy has been described by other authors in this volume, there are a number of policies of direct relevance to the oil and gas sector. Some of these policies directly address climate change mitigation, while others touch on related issues such as energy efficiency and the development of renewables. Ultimately however, the primary goal of Russian energy policy is to actively support the industry. The principle policy document pertaining to the oil and gas sector is the Energy Strategy to 2030. The stated primary goal is to maximise the efficient use of energy resources to ensure economic growth. Reference is made in the document to the need to reduce GHG emissions in the energy sector. Specific legislation that obliges companies to report their GHG emissions is currently under development (Davydova, 2017; Pravitel'stvo Rossii, 2018).

Russia's energy sector is highly inefficient by global standards, and consequently, there have been a number of attempts to introduce energy saving and efficiency measures. One of the most important of these is a decree ( Ukaz 889) issued by then President Medvedev on 4 June 2008 'On some measures to improve the energy and environmental efficiency of the Russian economy'. This aimed to reduce the energy intensity of the economy by at least $40 \%$ by 2020 , and called on the government to introduce a number of measures including new laws to encourage businesses to use energy-saving technology. Beyond this, the government introduced regulations in 2012 on the use of associated petroleum gas (APG), which has often been considered a waste product by the oil and gas industry, and burnt. A number of regulations 
have been put in place by the government to limit this practice, including a 2012 decree restricting flaring to no more than 5\% (Korppoo and Kokorin, 2017: 120-1). There have also been some attempts to encourage the use of and investment in renewable energy, with a number of government orders and decrees introduced (see Korppoo and Kokorin, 2017: 121). Despite considerable potential however, growth in renewables have been slow (IEA, 2014: 219). The analysis that follows considers the extent to which these policies have had an effect on Russia's oil and gas companies, in shaping their understanding and response to the issue.

\section{Methodology}

The Russian oil and gas sector has been chosen as the focus for analysis, given its significance for the Russian economy, and the sector's role as a major producer of GHG emissions. There is an additional goal of collating, comparing and analysing reporting from major Russian oil and gas companies and making the contents of these reports available to a wider audience.

To evaluate corporate responses to climate policy, a survey of the eight largest oil and gas companies according to the Ekspert 400 rankings (Ekspert.ru, 2017) was undertaken (see table 7.1 below). Together, these companies represent a substantial portion of Russia's oil and gas sector. Gazprom alone accounts for $66 \%$ of Russian gas output, which is $11 \%$ of global production (Gazprom, n.d.), and Rosneft is responsible for $40 \%$ of Russia's oil production, and $6 \%$ of global production (Rosneft, n.d.). Companies are both private, such as Lukoil, and stateowned corporations, such as Gazprom and Rosneft. ${ }^{2}$

\begin{tabular}{|l|l|}
\hline Company & $\begin{array}{l}\text { Volume of Sales in } 2016 \\
\text { (million rubles }\end{array}$ \\
\hline Gazprom
\end{tabular}




\begin{tabular}{|l|l|}
\hline Lukoil & 4743732,0 \\
\hline Rosneft & 4134000,0 \\
\hline Surgutneftegaz & 1020833,0 \\
\hline Tatneft & 580127,0 \\
\hline Novatek & 537472,0 \\
\hline Bashneft & 494722,0 \\
\hline Sakhalin Energy & 304810,0 \\
\hline
\end{tabular}

Table 7.1: Russia's largest oil and gas companies (Source: Ekspert.ru, 2017)

To assess what information about climate change mitigation efforts is disclosed, and identify corporate discourses on climate change, analysis was based on Sustainability Reports (SR), Environment Reports (ER), or Annual Reports (AR) where SR's or ER's were not available. Company websites were also examined. Sustainability, environmental, and annual reports are generally prepared in both Russian and English (with the exception of Bashneft, where only a Russian language SR was available). Where the English version has been used in this chapter, it has been checked against the Russian for consistency. Websites too are, for the most part, in both Russian and English. Some companies also prove other languages too: Sakhalin Energy for example has a Japanese language version. ${ }^{4}$

These reports, together with company websites, represent key forms of corporate communication. They enable corporations to advertise themselves and their agenda. This advertising is, for the most part, directed at company stakeholders, including investors, shareholders and the government, but also to the wider community. There is a vast literature on Corporate Social Responsibility (CSR) reporting, much of which concentrates on 
identifying motivations for firms in issuing these voluntary documents. This might be, for example, to demonstrate their commitment to the principles of CSR, or for 'greenwashing' purposes to influence stakeholder perceptions (Mahoney et al, 2013). There is also considerable discussion about the credibility of information (e.g. Michelon et al, 2015). The lack of independent verification of reported results and activities in these reports presents something of a challenge. However, despite issues with determining the accuracy of information, and the scepticism surrounding motivations for CSR disclosure, they remain a valuable tool for corporate actors to demonstrate their commitment to CSR (Allen and Craig, 2016). For the purposes of this research, corporate reporting on the environment from the Russian oil and gas sector helps us assess how companies want to be perceived by external actors and how the companies themselves regard certain issues. That is, are Russia's oil and gas companies interested in generating positive environmental PR by demonstrating how they address climate change, or is it low on the list of priorities?

The majority of companies provide SR's. These reports mostly follow a similar format, based on international reporting standards..$^{5}$ These documents provide information on corporate activities, including production results for the year, an overview of assets, new projects and future developments, and corporate governance. They also discuss environmental impact and management issues of the company, outline environmental priorities and spending. Reports cover a wide range of issues, including air, water and soil protection, waste management, and biodiversity conservation. Projects involving community groups and non-governmental organisations (NGOs) are discussed. Personnel, and health and safety issues are also covered in the SR and AR documents. Some companies, such as Gazprom and Surgutneftegaz, provide stand-alone environment reports, which concentrate specifically on company environmental policies and activities. 
Based on an analysis of the available documents, a series of key themes emerged that touched on the issue of climate in some form or another. Both climate specific (such as direct statements or positions on climate change, or reporting on GHG emissions and mitigation efforts) and climate related material (such as energy saving and efficiency measures, and investment in renewables) were included. Information about corporate non-climate environmental programs was also included for comparative purposes. These themes highlight the priorities of companies, and their understanding of the issue, and are used to build a picture of industry discourse on climate change.

\section{Industry framings of climate change}

Examining the environmental reporting contained within AR, SR and ER from Russia's oil and gas majors provides us with a valuable insight into how these large companies conceptualise the issue of climate change, and how companies think the issue should be addressed. This section first discusses direct references to climate change and identifies those corporate actors with clear positions on climate. Second, GHG emission reduction efforts are discussed together with the related issue of APG utilisation. Finally, corporate energy saving and efficiency measures are discussed.

\section{Stand-alone position on climate}

Of the companies surveyed, only Lukoil had a stand-alone position on climate change, although even this is limited in terms of what it covers. Lukoil's 'stance on climate change' states that the company takes an active part in discussions with the government on GHG regulation, and notes that Lukoil has developed its own system for managing emissions to respond to the issue of climate change (Lukoil, n.d. -c). A number of GHG reduction projects initiated by Lukoil 
are listed. Framed in market-based terms, it is noted that if these projects are successful, the 'ultimate goal could be to generate revenues by selling emission reduction units and to further reinvest the generated funds into new environmental and energy efficiency projects' (Lukoil, n.d. -c).

Further to its official 'stance' on climate, on the English version of the company's website, Lukoil 'as an environmentally responsible company, PJSC LUKOIL admits that global climate change prevention effort is extremely important' (Lukoil, n.d. -b). Similarly, on the Russian version of the website the company 'recognises the importance of measures to prevent global climate change, supports Russia's participation in global efforts to reduce emissions of greenhouse gases' (Lukoil, n.d. -c). Similar statements exist in the 2015-6 SR, where it is noted, for example, that 'LUKOIL acknowledges the importance of combating global climate change, and supports Russia's contribution to the global effort to reduce greenhouse gas emissions' (Lukoil, 2015-6: 49). It is significant that Lukoil establishes its support for international climate policy efforts and Russia's participation, as it is the only oil and gas company examined to explicitly do so.

However, despite this attention given to expressing direct support for climate policy efforts, Lukoil's strategies to address the issue are very similar to the other companies examined. For example, Lukoil's Health, Safety and Environmental Policy includes climate related goals including achieving a 'higher utilization ratio of associated petroleum gas', the 'increased output of eco-friendly fuels compliant with European standards', 'efficient control of greenhouse gas emissions', and the efficient use of natural resources through the 'introduction of resource-saving and energy efficient technologies and use of alternative energy sources' 
(Lukoil, n.d. -a). Other oil and gas companies also address these issues, as we will explore below.

While lacking a stand-alone company position on climate, a number of the other companies include statements addressing climate change as an issue in their corporate reporting. The deputy chair of Gazprom's Management Committee, Vitaly Markelov, for example, stated that 'Gazprom constantly improves the energy efficiency and reduces anthropogenic impact on the environment through the application of advanced technologies and equipment' and that the company 'takes part in solution [sic] of global air pollution issues by promoting natural gas as an environmentally safe motor fuel. Owing to the use of natural gas, energy balance of Russia is one of the "greenest" in the world' (Gazprom, 2016: 5). Again, we see a focus on energy efficiency as a central policy solution, and an emphasis on new technology. Markelov's statement also introduces the idea of natural gas as a green, climate-friendly source of energy, a sentiment (unsurprisingly) echoed by the big gas producers. Novatek too, for example, states that an intended aim of its environmental policy is to develop the market for 'environmentally safe' gas-engine fuels (Novatek, 2016b).

As we might expect, the need to balance climate mitigation efforts with economic concerns is a core element of the industry narrative. This is highlighted by Novatek, for example, which points to company participation in the Carbon Disclosure Project (CDP) and disclosure of information on GHG emissions and energy efficiency. Novatek's AR states that 'by taking part in these projects the Company intends to achieve a balance between the climate change risks and efficiency of investment projects' (Novatek, 2016a: 55). Surgutneftegaz's report also briefly mentions climate change, noting simply that 'the Company implements measures on 
prevention of global climate change, develops the corporate system of accounting and management of greenhouse gas emissions' (2016: 34).

Interestingly, there was little evidence to suggest climate change was considered a major risk to business operations to any large extent by the companies in question, despite the challenges posed by a changing climate, particularly in terms of physical risk to infrastructure and equipment. This is despite the frequent use of discourse on 'risk' to frame corporate responses to climate change observed by Wright and Nyberg for example (2015). The closest any company came to this idea of risk was Novatek, in its Environmental Policy. The policy sets out a number of environmental objectives and aims to "take into account the risks and assess the consequences of climatic changes for the activities of the company' (Novatek, 2016b). However, all companies did address physical risks in broader terms (oil spill and emergency situation preparations for example) in the AR \& SRs.

Finally, the companies examined did not appear to be heavily engaged with international developments in climate policy. Three companies (Gazprom, Bashneft and Sakhalin Energy) made reference to the Paris Agreement, but there was no discussion of content or implications for company operations (Bashneft, 2015: 44; Gazprom, 2016: 68; Sakhalin Energy, 2016: 72). Some clues were provided regarding company involvement in international bodies, with Rosneft, Lukoil and Sakhalin Energy, referring to participation in the UN Global Compact, a voluntary initiative designed at promoting sustainable business practices. They are the only Russian oil and gas companies involved, although none participate in the 'Caring for Climate Initiative' which is specifically aimed at addressing corporate responses to climate change. 


\section{GHG emissions and reduction efforts}

All companies surveyed reported their GHG emissions or air pollutant emissions (a broader category). Of note, however, is the fact that there were inconsistencies between the companies surveyed in regards to what is reported and how emissions are calculated. Sakhalin Energy, for example, calculates its emissions in accordance with the guidelines developed by the American Petroleum Institute (Sakhalin Energy, 2016: 72), while Novatek and Bashneft reports that they use the 2015 Russian government guidelines (Bashneft, 2015: 45; Novatek, 2016c: 76;). Four companies also report their emissions to the CDP: Lukoil, Gazprom, Surgutneftegaz and Novatek.

The lack of consistency in relation to GHG reporting is due to a gap in government policy. In January 2018, the government's commission on legislative activity had approved a draft bill which provides the legal framework to establish a system of reporting GHG emissions at the level of individual organisations (Pravitel'stvo Rossii, 2018). However, at the time of writing, the Ministry for Natural Resources was undertaking 'additional discussions' with the business community on the matter (TASS, 2018). It remains to be seen whether the bill will be submitted to parliament in its current form.

Stated measures for reducing GHG emissions are similar across the different companies surveyed, and usually fall within a company's broader energy saving plans. Gazprom, for example, prioritises GHG control as part of its corporate strategy, noting that 'energy saving practices and measures provide for the biggest GHG emission reduction at the gas transportation facilities' (Gazprom, 2016: 25). Rosneft claims to be 'working to lower its greenhouse gas emissions through initiatives provided in its Gas Investment Program and 
Energy Saving Program' (Rosneft, 2016: 74). Sakhalin Energy, in response to a stakeholder question about whether the company was planning further reductions in GHG emissions, claimed that 'the company is planning to maintain its current greenhouse gas emissions level at this stage. However, we are improving the energy efficiency of our assets as part of process optimisation. The implementation of these activities also has an effect on greenhouse gas emissions reduction' (Sakhalin Energy, 2016: 143).

A related issue concerns APG utilisation, or gas flaring, which is a major issue for the oil and gas industry. All eight companies identified APG utilisation as a priority, in line with government regulation, as noted above. A number of companies claim to have met the government's 95\% utilisation target, including Tatneft (96.44\%), Surgutneftegaz (99\%) and Sakhalin Energy (96.3\%). ${ }^{6}$ Lukoil, which is 'approaching the target of 95\%' (2015-6: 3), uses language to promote a 'green image' of the company, stating that, 'for over a decade, LUKOIL has been investing in APG utilization projects, having started its APG flaring reduction effort long before legislators made it mandatory' (2015-6: 47). In terms of framing however, little attempt is made to represent APG utilisation efforts as directly linked to climate change and emissions reduction efforts, and activities are reported within a wider framework of energy savings and efficient use of resources.

\section{Energy saving and efficiency}

All companies identified energy saving and efficiency as a key priority, and actively seek to promote their activities in this area as part of their environmental reporting. All companies have some kind of energy and resource saving program or policy. Rosneft's SR, for example, notes the company's success at meeting fuel and energy saving targets and states that 'lower operating costs resulting, in particular, from low fuel and energy consumption rates, along with 
higher production volumes are key for Rosneft to maintain its leading market positions' (Rosneft, 2016: 81). Similarly, Tatneft's AR points out that 'in the context of constantly growing tariffs of natural monopolies on energy resources, transportation services and increase of hydrocarbon production costs, the Company makes the comprehensive efforts to create maximum reserves for resource saving in all its business activities, including energy saving' (Tatneft, 2016: 52). The language used by companies to describe their efforts in this area demonstrates an economic framing of energy saving and efficiency.

A closely linked issue relates to industrial modernisation and an emphasis on new technology, which, similar to energy efficiency, corresponds to a market-based framing of climate change. While the Russian oil and gas companies surveyed did not draw direct links with climate policy, all AR and SR used language which focused on technology and modernisation. Igor Sechin's statement in Rosneft's SR highlights this point. Sechin, as CEO of the company, notes that 'striving to become a technology leader in the global energy sector, Rosneft consistently drives innovation by deploying new technologies, upgrading existing production processes and coming up with other initiatives' (Rosneft, 2016: 4). Lukoil, too, is 'focused on generating ideas, searching for and using new technologies (including those specifically aimed at reducing the consumption of natural resources), materials and energy with the highest output possible' (Lukoil, 2015-6: 21). Gazprom draws attention to its 'Innovative Development Program' which aims at the 'continuous improvement of technology' and 'technological leadership' to improve environmental safety and energy efficiency within the organisation (Gazprom, 2016: 64). Finally, Novatek and Rosneft both also make note of their involvement in best available technology 'technical working groups' (Novatek, 2016c: 26; Rosneft, 2016: 69), designed to develop guidelines for each industrial sector (Martus, 2017a: 279). The introduction of the 'best available technology' into Russian legislation has been a key development in recent years, and 
aims to use technology to improve environmental outcomes in industrial processes (Martus, 2017a).

There appears to be only minor interest amongst the companies sampled in renewable energy and investment. As noted above, government regulations are in place in Russia to encourage use of renewables (see Korppoo and Kokorin, 2017: 121), but with only limited effect so far. Lukoil, Novatek and Gazprom all make note of their use of renewables, with Lukoil reporting that $4 \%$ of 'total energy generated by the Company's power facilities is from renewables' (Lukoil, 2015-6: 20); and Novatek noting their use of solar panels and wind turbines along their pipelines (Novatek, 2016c: 77). Gazprom comments that it 'supports the use of alternative energy sources where it is economically and technically feasible', and provides a breakdown of generation by source (Gazprom, 2016: 49). However, none of the companies surveyed focus significant attention on the issue, suggesting that renewable energy use and investment is not a core part of corporate discourse on climate for oil and gas companies.

\section{Discussion}

A key issue to emerge from the analysis is how these industry narratives on climate change fit within a broader Russian and international context. That is, is the oil and gas industry exceptional in contrast with other sectors in Russia? How does the industry's framing of climate change compare with the international industry discourse on climate change?

Within the SR, ER and AR documents analysed, corporate reporting on climate policy and climate related policies was limited in comparison with other aspects of environmental action. When it comes to environmental protection, each of the companies surveyed provide extensive 
information about a range of issues, including waste and water management, and biodiversity conservation. They also all have some form of stand-alone policy on environmental protection, in contrast with climate. These documents or statements are used to set targets and identify key environmental tasks. As an example, Surgutneftegaz lists nine 'basic principles' in its environmental policy, including environmental monitoring, rational use of resources based on the implementation of 'innovative environmentally efficient and resource saving technologies' (Surgutneftegaz, 2016: 6). The company has a list of responsibilities to implement these principles, including tasks such as adhering to federal legislation, assessment of environmental risks and impact assessments, and improving environmental safety (Surgutneftegaz, 2016: 7). Information is also provided about stakeholder engagement. Both Lukoil and Rosneft make note of joint activities with the WWF Russia for example. Lukoil, according to its report, signed a cooperation agreement with WWF, and conducted joint expeditions with the Marine Mammal Council to monitor walrus populations in the Barents Sea (Lukoil, 2015-6: 42). According to its SR, Rosneft consulted with the WWF on preserving biodiversity and reducing the impact of oil spills (Rosneft, 2016: 68). This does not mean these activities are necessarily anything more than 'environmental PR'; many of the tasks set by companies are vague with little clue given as to how they will be implemented, or they are tasks required by law anyway. AR and SR documents do not contain independent verification of company activities. However, what is demonstrated by this analysis, is that the level of attention paid to the environment, in contrast with climate issues, is significantly higher.

While extensive research across economic sectors in Russia is lacking, a study by the present author of Russia's metals and mining sector provides a useful comparison (Martus, 2018). Similar to the oil and gas sector, the majority of metals and mining companies surveyed had a focus on energy saving and efficiency. As noted above, energy saving and efficiency measures 
have been a core focus of government climate policy efforts, and so we can consider oil and gas framing of the issue to be closely aligned with both the government and the metals and mining sector on this issue.

Beyond energy efficiency however, differences emerge. The metals and mining companies were characterised by strong variation within the sector in terms of response to climate change and associated policy developments. While some companies were not supportive of action on climate, and either actively resisted or were found to be disengaged from the political discussion, a number of companies took a proactive role and sought to lobby the government to introduce GHG mitigation regulation and encourage greater Russian participation in international policy debates (Martus, 2018: 9). Aluminium company Rusal, and its oligarch owner Oleg Deripaska, was particularly active in this regard. Several companies had position statements broadly supportive of domestic and international efforts to address climate change, and joined domestic or international business partnerships such as the Climate Partnership of Russia or the UN Global Compact 'Caring for Climate', aimed at coordinating business commitments on climate (4-5)?. This level of activity was not found amongst the oil and gas companies examined. As noted above, Lukoil was the only company to have an official position on climate change and the only one to state that it supported international efforts to combat climate change. However, even this appeared limited, and beyond expressing support, Lukoil did not appear to play an active role in climate policy debates within Russia or internationally. On the whole, the variation present within the metals and mining sector was not found to be as significant in the case of Russian oil and gas companies, with the majority of them displaying very limited interest in climate policy and GHG mitigation efforts. 
International comparisons are hampered by a relative lack of sector specific research. We would not expect a lack of interest or active disregard of climate mitigation policies to be unusual amongst global oil and gas majors. Although, as noted above, a number of works have pointed to the significant divergence in policy responses amongst oil and gas companies, particularly from the late 1990s. ExxonMobil for example is identified as a major opponent of climate policy, while other companies such as BP and later Shell took a more supportive stance (e.g. Skjærseth \& Skodvin, 2001; van den Hove et al, 2002; Pulver, 2007). However, we would ultimately expect fossil fuel companies, both in Russia and globally, to be some of the most resistant to climate policy, given that climate change mitigation efforts therefore pose a threat to the operations of these companies.

\section{Conclusion}

This chapter has focused on industry and its understanding of climate change, as an important part of the broader discourse on climate change within Russia. As examined, all of the oil and gas majors present their plans to reduce GHG emissions and air pollutants, and outline measures to reduce gas flaring. Energy efficiency and resource saving measures are explained in each report, and there is an emphasis on technology and industrial modernisation as a way of addressing the challenges presented by climate change and protecting the environment more broadly. The analysis provides clear evidence on an industry discourse on climate very much set within a market based framework. It also highlights the lack of policy ambition on the part of the government, with delays to GHG reporting requirements and policies to encourage renewables that appear to be of limited interest for oil and gas companies.

So, while climate related issues such as energy saving and efficiency do receive attention, there are clear limits on the extent to which oil and gas companies are prepared to engage. As we 
have seen, there is only very limited direct discussion of climate change, with only one company surveyed issuing a stand-alone position on climate. There was little to no engagement on domestic or international policy developments, in contrast to some companies within the Russian metals and mining sector as noted. While some attention was given to maintaining a 'green' reputation, the evidence suggested that climate was peripheral to this image. Finally, few companies gave consideration to the risk posed to their operations by a changing climate. For the most part, climate change seems to be of low importance for Russia's oil and gas sector. 


\section{References}

Allen, M. and Craig, C. (2016) 'Rethinking corporate social responsibility in the age of climate change: a communication perspective', International Journal of Corporate Social Responsibility, vol 1, no 1, DOI 10.1186/s40991-016-0002-8.

Andonova, L. B. (2008) 'The climate regime and domestic politics: the case of Russia', Cambridge Review of International Affairs, vol 21, no 4, pp483-504

Bashneft (2015) 'Otchet ob ustoichivom razvitii', http://www.bashneft.com/files/iblock/faa/20160617_bn_our2015_web_rus.pdf Bulkeley, H. and Newell, P. (2015) Governing Climate Change. Routledge, London. Davydova, A. (2017) 'Parnikovye gazy vpisyvaiut v zakon: kompanii obiazhut otchityvat'sia ob ikh vybrosakh', Kommersant, 1 March, https://www.kommersant.ru/doc/3229089 Ekspert.ru (2017) 'Ekspert 400: reiting krupneishikh rossiiskikh kompanii', http://expert.ru/dossier/rating/expert-400/

Gazprom (2016) 'PJSC Gazprom Environmental Report 2016’, http://www.gazprom.com/f/posts/44/307258/gazprom-ecology-report-2016-en.pdf

Gazprom (n.d.) 'O Gazprome’, http://www.gazprom.ru/about/

Gustafson, T. (2012) Wheel of Fortune: The Battle for Oil and Power in Russia, Belknap Press, Cambridge

Hajer, M. (1995) The Politics of Environmental Discourse: Ecological Modernization and the Policy Process. Oxford University Press, Oxford

Hoffman, A. (2005) 'Climate change strategy: the business logic behind voluntary greenhouse gas reductions', California Management Review, vol 47, no 3, pp21-46 
International Energy Agency (IEA) (2014) Russia 2014, IEA Publications, https://www.iea.org/publications/freepublications/publication/russia-2014---energy-policiesbeyond-iea-countries.html

Jones. C. and Levy D. (2007) 'North American business strategies towards climate change', European Management Journal, vol 25 no 6, pp428-440

Kolk, A. and Pinkse, J. (2007) 'Multinationals' political activities on climate change', Business \& Society, vol 46 no 2, pp201-228

Korppoo, A. and Kokorin, A. (2017) 'Russia's 2020 GHG emissions target: Emission trends and implementation', Climate Policy, vol 17 no 2, pp113-130

Korppoo, A. (2007) 'Joint implementation in Russia and Ukraine: review of projects submitted to JISC', Climate Strategies Briefing Paper, October, http://climatestrategies.org/publication/joint-implementation-in-russia-and-ukraine-reviewof-projects-submitted-to-jisc/

Levy, D. and Kolk, A. (2002) 'Strategic responses to global climate change: conflicting pressures on multinationals in the oil industry', Business and Politics, vol 4 no 3, pp275-300

Levy, D. (2005) 'Business and the evolution of the climate regime: the dynamics of corporate strategies', in D. Levy and P. Newell (eds) The Business of Global Environmental Governance. MIT Press, Cambridge, pp73-104

Livesey, S. (2002) 'Global warming wars: rhetorical and discourse analytic approaches to ExxonMobil's corporate public discourse', The Journal of Business Communication, vol 39, no 1, pp117-148 
Lukoil (2015-6) 'Lukoil Group Sustainability Report 2015-2016’, http://www.lukoil.com/InvestorAndShareholderCenter/ReportsAndPresentations/Sustainabilit yReport

Lukoil (n.d, -a) 'Health, safety and environment policy implemented by the open Joint Stock Company "Oil Company Lukoil” in the twenty-first century', http://www.lukoil.com/Responsibility/SafetyAndEnvironment/HSEManagementSystem/HSE Policy

Lukoil (n.d, - b) 'Lukoil's Stance on Climate Change', http://www.lukoil.com/Responsibility/SafetyAndEnvironment/Ecology/GasEmissionRegulati on

Lukoil (n.d, - c) ‘Pozitsiia PAO ‘Lukoil’ po Probleme Izmeneniia Klimata, http://www.lukoil.ru/Responsibility/SafetyAndEnvironment/Ecology/GasEmissionRegulatio n

Mahoney, L. S., Thorne, L., Cecil, L. and LaGore, W.. (2013) 'A research note on standalone corporate social responsibility reports: signaling or greenwashing?', Critical Perspectives on Accounting, vol 24, no 4-5, pp350-359

Martus, E. (2017a) 'Contested policymaking in Russia: industry, environment, and the "best available technology" debate', Post-Soviet Affairs, vol 33 no 4, pp276-297

Martus, E. (2017b) Russian Environmental Politics: State, Industry and Policymaking. Routledge, Abingdon

Martus, E. (2018) 'Russian industry responses to climate change: the case of the metals and mining sector, Climate Policy, https://doi.org/10.1080/14693062.2018.1448254 
Meckling, J. (2011) 'The globalization of carbon trading: transnational business coalitions in climate politics', Global Environmental Politics, vol 11 no 2, pp26-50

Michelon, G., Pilonato, S. and Ricceri, F. (2015) 'CSR reporting practices and the quality of disclosure: An empirical analysis', Critical Perspectives on Accounting, vol 33, pp59-78

Ministerstvo Finansov Rossiiskoi Federatsii (2018) 'Ezhegodnaia informatsiia ob ispolnenii federal'nogo biudzheta' (dannye ot 1 ianvaria 2006 g.),

https://www.minfin.ru/ru/statistics/fedbud/\#

Ministerstvo Prirodnykh Resursov (2017, 2 June) 'V ramkakh PMEF proshli rossiiskonemetskie peregovory, kasaiushchiesia Strategii ekonomicheski priemlemoi realizatsii Parizhskogo soglasheniia', http://www.mnr.gov.ru/news/detail.php?ID=342877

Newell, P. and Paterson, M. (1998) 'A climate for business: global warming, the state and capital', Review of International Political Economy, vol 5, no 4, pp679-703

Novatek (2016a) ‘Annual Report’, http://www.novatek.ru/en/investors/reviews/ Novatek (2016b) 'Politika PAO "Novatek” v oblasti okhrany okruzhaiushchei sredy promyshlennoi bezopasnosti i okhrany truda', approved 25 April 2016

Novatek (2016c) ‘Sustainability Report', http://www.novatek.ru/en/development/ Pulver, S. (2007) 'Making sense of corporate environmentalism', Organization \& Environment, vol 20 no 1, pp44-83

Pravitel'stvo Rossii (2018, 9 January) ‘Komissiia po zakonoproektnoi deiatel'nosti odobrila zakonoproekt o sisteme otchetnosti ob ob' 'emakh vybrosov parnikovykh gazov', http://government.ru/dep_news/30901/

Rosneft (2016) 'Rosneft Sustainability Report', https://www.rosneft.com/Development/Sustainability_Reports/ 
Rosneft. 'Rosneft at a glance', https://www.rosneft.com/about/Rosneft_today/

Sakhalin Energy (2016) 'Sustainable Development Report 2016’, http://www.sakhalinenergy.ru/media/user/otchety/GRI_report_2016_eng.pdf

Skjærseth J.B. and Skodvin, T. (2001) 'Climate change and the oil industry: common problems, different strategies', Global Environmental Politics, vol 1, no 4, pp43-64.

Surgutneftegaz (2016) 'OJSC Surgutneftegas Environmental Report', http://www.surgutneftegas.ru/en/ecology/reports/

TASS (2018, 16 February) 'Sergei Donskoi: govorit' o stabilizatsii rynka nefti rano', http://tass.ru/forumsochi2018/articles/4962147

Tatneft (2016) 'Tatneft Company Annual Report', http://www.tatneft.ru/forshareholders/information-disclosure/annual-report/?lang=en

Taylor, C. (2013) 'The discourses of climate change', in T. Cadman (ed) Climate Change and Global Policy Regimes: Towards Institutional Legitimacy. Palgrave, Basingstoke, pp17-31

UNFCCC (2015) GHG emission profiles: Russian Federation, http://unfccc.int/files/ghg_emissions_data/application/pdf/rus_ghg_profile.pdf. van den Hove, S., Le Menestrel, M. and de Bettignies, H. (2002) 'The oil industry and climate change: strategies and ethical dilemmas', Climate Policy, vol 2 no 1, pp3-18

Wright, C. and Nyberg, D. (2015) Climate change, capitalism, and corporations: processes of creative self-destruction. Cambridge University Press, Cambridge.

\footnotetext{
${ }^{1}$ For more detail on the sector, see Martus (2017b: 89-91)

${ }^{2}$ For a comparison of the environmental policies of Rosneft and Gazprom, see Martus (2017b: 95-6).

${ }^{3}$ \$1US $=57.73$ RUB as of December 2017

${ }^{4}$ Japan represents an important export market for the company, accounting for $67 \%$ of LNG sales and $36 \%$ if oil blend sales in 2016 (Sakhalin Energy, 2016: 25).
} 
${ }^{5}$ In the sample selected here, all companies with the exception of Gazprom and Surgutneftegaz, used the Global Reporting Initiative (GRI) standards.

${ }^{6}$ Tatneft (2016: 267); Surgutneftegaz (2016: 3); Sakhalin Energy (2016: 73). 